\title{
Cloning, expression in Komagataella phaffii, and biochemical characterization of recombinant sequence variants of Pseudomonas sp. S9 GDSL-esterase*
}

\author{
Monika Wicka-Grochocka, Hubert Cieśliński and Marta Wanarska® \\ Department of Molecular Biotechnology and Microbiology, Faculty of Chemistry, Gdańsk University of Technology, Gdańsk, Poland
}

Two recombinant Komagataella phaffii (formerly Pichia pastoris) yeast strains for production of two sequential variants of EstS9 esterase from psychrotolerant bacterium Pseudomonas sp. S9, i.e. aEstS9N (a two-domain enzyme consisting of a catalytic domain and an autotransporter domain) and aEstS9 $\Delta$ (a single-domain esterase) were constructed. However, only one of recombinant $K$. phaffii strains, namely Komagataella phaffii X-33/ pPICZaestS9 $\Delta$, allowed to successfully produce and secrete recombinant aEstS9 $\Delta$ enzyme outside of the host cell. The purified aEstS9 $\Delta$ esterase was active towards short-chain $p$-nitrophenyl esters (C2-C8), with optimal activity for the acetate (C2) ester. The single-domain aEstS9 $\Delta$ esterase exhibits the highest activity at $60^{\circ} \mathrm{C}$ and $\mathrm{pH}$ 9.5. In addition, the enzyme retains $90 \%$ of its activity after 3 hour incubation at $70-90^{\circ} \mathrm{C}$. What should be also noted is that aEstS9 $\Delta$ esterase produced in the $K$. phaffii expression system has a much higher specific activity $(0.069 \mathrm{U} / \mathrm{mg}$ of protein) than the recombinant EstS9 $\Delta$ esterase produced in an $E$. coli expression system $(0.0025 \mathrm{U} / \mathrm{mg}$ of protein) (Wicka et al., 2016, Acta Biochim Pol 63: 117-125. https://doi.org/10.18388/ abp.2015_1074).

Key words: GDSL-esterase, autotransporter, single-domain esterase, Pseudomonas sp. S9, Komagataella phaffii

Received: 03 June, 2021; revised: 25 July, 2021; accepted: 26 July, 2021; available on-line: 25 August, 2021

घe-mail: marta.wanarska@pg.edu.pl

*This paper is dedicated to Professor Wacław Tadeusz Szybalski on the 100th anniversary of his birth

\section{INTRODUCTION}

Lipolytic enzymes, due to their unique properties, such as the chemo-, regio-, and enantioselectivity, and the ability to catalyze reactions both in the aqueous and non-aqueous media, have become one of the most important groups of biocatalysts. They are mainly used in the detergent industry as additives in the laundry detergents, as well as in the food, pharmaceutical and organic synthesis industries (Jaeger \& Eggert, 2002).

Due to their substrate specificity, lipolytic enzymes can be divided into lipases and esterases. Esterases catalyze hydrolysis of smaller ester molecules than lipases, partially water-soluble triacylglycerols, having short chains of monocarboxylic acids with less than 10 carbon atoms (Jaeger \& Eggert, 2002).

Bacterial lipolytic enzymes were divided into eight families. This division was created based on the analysis of their amino acid sequences and their biological functions (Hausmann \& Jaeger, 2010). Lipolytic enzymes belonging to the II family, in contrast to the $\alpha / \beta$-hydrolase fold lipolytic enzymes, contain the active-site serine residue in a conserved Gly-Asp-Ser-Leu (GDSL) motif instead of the usually occurring evolutionally conserved pentapeptide Gly-Xaa-Ser-Xaa-Gly. The family of GDSL hydrolases was established in 1995 (Upton \& Buckley, 1995). Some GDSL hydrolases share an additional domain located at the $\mathrm{C}$-terminus of the respective proteins. This domain consists of $12 \beta$-sheets which form a $\beta$-barrel inserted into the bacterial outer membrane. The N-terminal part of these GDSL hydrolases responsible for enzymatic activity is exported through this $\beta$-barrel. Enzymes of this group, termed autotransporters, have been identified in several pathogenic bacteria and are responsible for virulence of these microorganisms (Hausmann \& Jaeger, 2010).

The EstS9 enzyme from psychrotolerant bacteria Pseudomonas sp. S9 is comprised of two domains: an N-terminal catalytic domain and a C-terminal autotransporter domain. Therefore, in our previous study (Wicka et al., 2016), we tested the suitability of an E. coli expression system (pBAD expression system) for the production of two sequential EstS9 esterase variants, i.e. EstS9N and EstS9 $\Delta$ proteins. Recombinant EstS9N was comprised of an N-terminal catalytic domain and C-terminal autotransporter domain of EstS9 esterase fused with the His-tag domain, whereas recombinant EstS9 $\Delta$ was comprised of an N-terminal catalytic domain of EstS9 esterase fused with the His-tag domain. However, despite the differences in molecular structures, amino acid sequences and size of these recombinant enzymes, both EstS9N and EstS9 $\Delta$ were produced as insoluble inclusion bodies in the E. coli cells. Unfortunately, after purification of both recombinant enzymes under denaturing conditions and renaturation, only EstS9N esterase was stable during storage and revealed remarkably higher enzymatic activity than the one observed for the purified EstS9 $\Delta$ esterase. Hence, in our previous work, despite low purification efficiency of the recombinant enzyme from inclusion bodies, we could only characterize the EstS9N esterase.

Therefore, in this study we decided to test an alternative expression system based on methylotrophic Komagataella phaffii (formerly Pichia pastoris) yeast as the host because of the confirmed ability of this yeast to secrete recombinant proteins into the culture medium (Ahmad et al., 2014; Spohner et al., 2015). We choose the strong, methanol inducible $A O X 1$ promoter for expression of aest $59 N$ and aestS9 $\triangle$ genes to enable efficient production and secretion of both sequential variants of Pseudomonas sp. S9 esterase. However, in this case only the $\alpha$ EstS9 $\Delta$ 
recombinant enzyme, a single-domain variant of the EstS9 esterase, was obtained and characterized.

\section{MATERIALS AND METHODS}

\section{Bioinformatics analyses}

Bioinformatics analyses of amino acid sequences of $\alpha$ EstS9N and $\alpha$ EstS9 $\Delta$ proteins were done with bioinformatics tools used in our previous study (WierzbickaWoś et al., 2013), but the PSORT program was not used here. Topographic presentations of the Pfam domains for $\alpha$ EstS9N and $\alpha$ EstS9 $\Delta$ enzymes were done with the MyDomains - Image Creator (http://prosite.expasy.org/ mydomains/). Dot blot results were analyzed using the Quantity One Software v. 4.5 (Bio-Rad, USA).

\section{Construction of $K$. phaffii X-33/pPICZaestS9N and K. phaffii X-33/pPICZaestS9 $\Delta$ strains}

The first PCR product, called aestS9N, was obtained using the following primers: Forward $\alpha$ EstAutoXhoI ATGCCTCGAGAAAAGAGCGCCTAATCCTTACACCCATTTCGTC and ReverseEstAutoXbaI GAGCTCTAGATAGAAGTCCAGCGCAACGCCTACATTAA. The second DNA fragment, called $\alpha$ estS9 $\Delta$, was PCR amplified using the Forward $\alpha$ EstAutoXhoI primer (as above) and ReverseEstXbaI primer CATGTCTAGAAGGCGTTGCCCTGCTTCGGTC. The XhoI restriction site was incorporated into the sequence of the forward primer and $\mathrm{XbaI}$ sites were incorporated into the sequences of both reverse primers. The recognition sites for the above mentioned restriction endonucleases are underlined in the sequences of presented primers and were designed to facilitate cloning. Sequences complementary to the template, i.e. genomic DNA of Pseudomonas sp. S9 (Wicka et al., 2016), are given in bold. The thermal cycling conditions were the same in both PCRs performed using Phusion ${ }^{\mathrm{TM}}$ High-Fidelity DNA Polymerase (Thermo Fisher Scientific, USA): initial denaturation at $98^{\circ} \mathrm{C}$ for $30 \mathrm{~s}$, next 30 cycles with denaturation at $98^{\circ} \mathrm{C}$ for $10 \mathrm{~s}$, annealing at $63^{\circ} \mathrm{C}$ for $30 \mathrm{~s}$, extension at $72^{\circ} \mathrm{C}$ for $60 \mathrm{~s}$ and a final extension at $72^{\circ} \mathrm{C}$ for $5 \mathrm{~min}$.

The $\alpha$ estS9N and the $\alpha$ estS9 $\Delta$ PCR products were purified using the Extractme DNA Clean-Up kit (Blirt S.A., Poland), then digested with XhoI and XbaI restriction endonucleases (Thermo Fisher Scientific, USA), and purified by ethanol precipitation. Each purified DNA fragment was separately ligated to $\mathrm{PPICZ} \alpha$ A expression vector (EasySelect ${ }^{\mathrm{TM}}$ Pichia Expression Kit; Invitrogen, USA), previously digested with the same endonucleases. Then, the ligation products were used to transform chemically competent E. coli TOP10 cells (Invitrogen, USA). After transformation, E. coli TOP10 cells were plated on LB low salt agar $(0.5 \%$ yeast extract, $1.0 \%$ peptone, $1.5 \%$ agar, $0.5 \% \mathrm{NaCl}$ ) containing Zeocin (Invitrogen, USA) at $25 \mu \mathrm{g} / \mathrm{mL}$, and incubated at $37^{\circ} \mathrm{C}$ for $24 \mathrm{~h}$. Then, all plates were analyzed for the presence of recombinant E. coli TOP10/pPICZ $\alpha$ estS9N and E. coli TOP10/pPICZ $\alpha$ estS9 $\Delta$ colonies. The recombinant bacterial strains were grown in LB low salt medium containing Zeocin and pPICZ $\alpha$ estS9N and pPICZ $\alpha$ estS9 $\Delta$ plasmids were then isolated with the ExtractMe Plasmid DNA Kit (Blirt S.A., Poland). Thus obtained plasmid constructs were validated by restriction analysis and DNA sequencing (Genomed, Poland).
Next, the recombinant plasmids pPICZ $\alpha$ estS9N and pPICZ aestS9 $\Delta$ were linearized with PmeI restriction endonuclease (New England Biolabs, USA) and used to transform competent $K$. phaffii X-33 cells by electroporation. The $K$. phaffii X-33 strain was prepared for electroporation according to the $\mathrm{pPICZ} \alpha \mathrm{A}, \mathrm{B}$, and $\mathrm{C}$ Pichia expression vectors for selection on Zeocin ${ }^{\mathrm{TM}}$ and purification of secreted, recombinant proteins user manual (Invitrogen, USA). Then, $40 \mu \mathrm{L}$ of yeast cells were mixed with $5 \mu \mathrm{g}$ of linearized plasmid DNA, incubated on ice for $5 \mathrm{~min}$ and transferred to an ice-cold 0.2 $\mathrm{cm}$ electroporation cuvette. The expotential decay pulse (1.5 kV, $5 \mathrm{~ms}$ ) was performed using the Gene Pulser

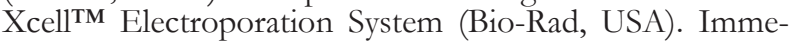
diately after the pulse, $1 \mathrm{~mL}$ of ice-cold $1 \mathrm{M}$ sorbitol was added to the cuvette. The cuvette contents were transferred to a $15 \mathrm{~mL}$ tube and incubated at $30^{\circ} \mathrm{C}$ for $2 \mathrm{~h}$. Subsequently, $1 \mathrm{ml}$ of the YPD medium $(1.0 \%$ yeast extract, $2.0 \%$ peptone, $2 \%$ D-glucose) was added and the tube was incubated for another $3 \mathrm{~h}$ at $30^{\circ} \mathrm{C}$ with shaking (180 rpm). Transformants were then plated on YPDS agar $(1.0 \%$ yeast extract, $2.0 \%$ peptone, $2.0 \% \mathrm{D}$-glucose, $2.0 \%$ agar and $1 \mathrm{~mol} / \mathrm{L}$ of D-sorbitol) containing 100 $\mu \mathrm{g} / \mathrm{mL}$ Zeocin (Invitrogen, USA), and incubated at $30^{\circ} \mathrm{C}$ for 5 days.

Next, the recombinant $K$. phaffii cells from all colonies were transferred onto YPD agar plates $(1.0 \%$ yeast extract, $2.0 \%$ peptone, $2.0 \%$ D-glucose, $2 \%$ agar) containing 100, 250, 500 or $1000 \mu \mathrm{g} / \mathrm{mL}$ Zeocin (Invitrogen, USA). The plates were incubated at $30^{\circ} \mathrm{C}$ for the next 5 days until colonies were formed. Transformants from YPD-agar plates with the highest concentration of Zeocin $(1000 \mu \mathrm{g} / \mathrm{mL})$ were cultivated in the YPD medium supplemented with Zeocin $(100 \mu \mathrm{g} / \mathrm{mL})$ at $30^{\circ} \mathrm{C}$ for $72 \mathrm{~h}$ with shaking at $180 \mathrm{rpm}$. Afterwards, the genomic DNA from recombinant yeast strains $K$. phaffii X-33/ pPICZ $\alpha$ estS9N and K. phaffii X-33/pPICZ $\alpha$ estS9D was isolated by the ExtractMe DNA Yeast Kit (Blirt S.A., Poland), and assessed by PCR with Forward $\alpha$ EstAutoXhoI and ReverseEstAutoXbaI or Forward $\alpha$ EstAutoXhoI and ReverseEstXbaI primers, respectively.

\section{Small-scale expression of aestS9N and aestS9D genes in K. phaffii X-33 cells}

The K. phaffii X-33/pPICZaestS9N and K. phaffii $\mathrm{X}-33 / \mathrm{pPICZ} \alpha \mathrm{estS} 9 \Delta$ strains were grown in $25 \mathrm{~mL}$ of the BMGY medium $(10 \mathrm{~g} / \mathrm{L}$ of yeast extract, $20 \mathrm{~g} / \mathrm{L}$ of peptone, $13.4 \mathrm{~g} / \mathrm{L}$ of yeast nitrogen base, $4 \times 10^{-4} \mathrm{~g} / \mathrm{L}$ of biotin, $10 \mathrm{~mL} / \mathrm{L}$ of glycerol and $0.1 \mathrm{~mol} / \mathrm{L}$ of potassium phosphate buffer, $\mathrm{pH}$ 6.0) in $250 \mathrm{~mL}$ flasks at $30^{\circ} \mathrm{C}$ for $18 \mathrm{~h}$ with shaking $(180 \mathrm{rpm})$. After centrifugation of the yeast cultures, the cell pellets were resuspended in 50 $\mathrm{mL}$ of the BMMY medium (BMMY, in contrast to the BMGY medium, contains $5 \mathrm{~mL} / \mathrm{L}$ of methanol instead of glycerol) in $500 \mathrm{~mL}$ flasks and cultivated for $96 \mathrm{~h}$ at $25^{\circ} \mathrm{C}$ with shaking at $180 \mathrm{rpm}$. The cultures were supplemented with methanol every $24 \mathrm{~h}$ to its final concentration of $0.5 \%$ to induce expression of the aestS9N and aestS9 $\Delta$ genes in $K$. phaffii X-33 cells.

Finally, the post-culture media were separated from the yeast cells by centrifugation at $3500 \times \mathrm{g}$ for $5 \mathrm{~min}$. The cell pellets were resuspended in $20 \mathrm{mM}$ Tris- $\mathrm{HCl}$ buffer $\mathrm{pH} 7.5$ and cells were disrupt using glass beads (212-300 $\mu \mathrm{m}$, Sigma). The cell lysates were then centrifuged at $3500 \times g$ for $5 \mathrm{~min}$ to obtain cell-free extracts. The presence of recombinant proteins in post-culture media, cell lysates and cell-free extracts was tested by 
a dot blot method using HRP conjugated anti-His antibodies (Sigma).

\section{Production and purification of the aEstS9 $\Delta$ esterase}

The K. phaffii X-33/pPICZ $\alpha$ estS9 $\Delta$ strain was grown in $150 \mathrm{~mL}$ of the BMGY medium, in a $1 \mathrm{~L}$ flask, at $30^{\circ} \mathrm{C}$ for $18 \mathrm{~h}$ with agitation $(180 \mathrm{rpm})$. After centrifugation of the yeast culture, the cell pellet was resuspended in $300 \mathrm{~mL}$ of the BMMY medium in a $2 \mathrm{~L}$ flask and incubated at $25^{\circ} \mathrm{C}$ for $96 \mathrm{~h}$ with agitation $(180 \mathrm{rpm})$. The yeast culture was supplemented with methanol every $24 \mathrm{~h}$ to the final concentration of $0.5 \%$ to induce expression of the aest59 $\Delta$ gene in the $K$. phaffii X-33 cells.

Next, the post-culture fluids from six yeast cultures were pooled and concentrated using a cross-flow ultrafiltration cassette with a molecular weight limit of $30 \mathrm{kDa}$ (VIVA FLOW 50R, Sartorius Stedim Biotech GmbH, Germany), followed by exchange of the culture medium with a B5 buffer $(20 \mathrm{mM}$ Tris- $\mathrm{HCl}, 500 \mathrm{mM} \mathrm{NaCl}$, $5 \mathrm{mM}$ imidazole, $\mathrm{pH}$ 7.9). The concentrated sample was applied onto an Ni-NTA column pre-equilibrated with the B5 buffer. Then, the Ni-NTA column was washed with an imidazole gradient from 5 to $60 \mathrm{mM}$ in the B5 buffer. Finally, the elution step was carried out with an E500 buffer (20 mM Tris-HCl, $500 \mathrm{mM} \mathrm{NaCl}, 500 \mathrm{mM}$ imidazole, $\mathrm{pH} 7.9$ ) at a flow rate of $0.5 \mathrm{~mL} / \mathrm{min}$.

The obtained protein sample was desalted using a VIVA FLOW 50R ultrafiltration cassette with a molecular weight limit of $30 \mathrm{kDa}$ and $20 \mathrm{mM}$ Tris- $\mathrm{HCl}$ buffer $\mathrm{pH} 7.5$.

Molecular weight of the $\alpha \mathrm{EstS} 9 \Delta$ protein was estimated by SDS-PAGE (Bollag \& Edelstein, 1991). Protein concentration was determined spectrophotometrically by the Bradford method (Bollag \& Edelstein, 1991), using the commercially available Quick Start Bradford Protein Assay (Bio-Rad, USA).

\section{Effects of temperature and $\mathrm{pH}$ on aEstS9 $\Delta$ esterase activity and stability}

The effect of temperature on the $\alpha$ EstS9 $\Delta$ esterase activity was assayed by incubating the reaction mixtures at temperatures ranging from 5 to $85^{\circ} \mathrm{C}$ (in $5^{\circ} \mathrm{C}$ increments) and $\mathrm{pH} 7.5$ (20 mM Tris- $\mathrm{HCl}$ buffer). Each reaction mixture contained $p$-nitrophenyl butyrate at a final concentration of $3.6 \mathrm{mM}$ as the substrate. The enzymatic reactions were stopped after $40 \mathrm{~min}$ with isopropanol, and the absorbance of all analyzed mixtures was measured at $405 \mathrm{~nm}$.

The optimum $\mathrm{pH}$ was determined by assaying the esterolytic activity of the $\alpha$ EstS9 $\Delta$ enzyme in a $10 \mathrm{mM}$ Britton-Robinson buffer, with $\mathrm{pH}$ values ranging from 2.0 to 12.0 . The esterolytic activity in each analyzed reaction mixture was quantitated at $35^{\circ} \mathrm{C}$ with $p$-nitrophenyl butyrate $(3.6 \mathrm{mM})$ as the substrate. The enzymatic reactions in all analyzed mixtures were stopped after $40 \mathrm{~min}$ with isopropanol, and the absorbance was measured at $405 \mathrm{~nm}$.

For the thermal stability assays, the purified enzyme was pre-incubated at temperatures ranging from 40 to $90^{\circ} \mathrm{C}$ (in $10^{\circ} \mathrm{C}$ increments) in the absence of the substrate in reaction mixtures. After incubation for different times $(20,40,80,180$ and $300 \mathrm{~min})$, the esterolytic activity of $\alpha$ EstS9 $\Delta$ against $p$-nitrophenyl butyrate $(3.6 \mathrm{mM}$ ) was measured by assaying the residual activity of the enzyme at $\mathrm{pH} 9.0$ and $35^{\circ} \mathrm{C}$ for $40 \mathrm{~min}$.

For the $\mathrm{pH}$ stability assays, the reaction mixtures containing the purified enzyme were incubated at $35^{\circ} \mathrm{C}$ and $\mathrm{pH}$ ranging from 6.0 to 11.0 . After incubation for 20,40 and $60 \mathrm{~min}$, small samples of the mixtures were withdrawn, and the residual enzymatic activities were measured with p-nitrophenyl butyrate in $20 \mathrm{mM}$ Tris- $\mathrm{HCl}$ buffer $\mathrm{pH} 9.0$ at $35^{\circ} \mathrm{C}$. The enzymatic reactions were stopped after $40 \mathrm{~min}$ with isopropanol.

\section{Effects of selected metal ions and reagents on the enzymatic activity of aEstS9 $\Delta$}

The effects on the $\alpha$ EstS9 $\Delta$ esterase activity of dithiothreitol (DTT), oxidized glutathione, reduced glutathione, $\beta$-mercaptoethanol, ethylenediaminetetraacetic acid disodium salt (EDTA), and salts of selected metal ions $\left(\mathrm{Mg}^{2+}, \mathrm{Ca}^{2+}, \mathrm{Mn}^{2+}, \mathrm{Ni}^{2+}, \mathrm{Co}^{2+}\right)$ at final concentrations of $5 \mathrm{mM}$, were assayed for $40 \mathrm{~min}$ at $35^{\circ} \mathrm{C}$ in $20 \mathrm{mM}$ Tris$\mathrm{HCl}$ buffer $\mathrm{pH} 9.0$, with $3.6 \mathrm{mM}$ p-nitrophenyl butyrate as the substrate.

\section{Substrate specificity of aEstS9 $\Delta$ esterase}

The substrate specificity of the purified $\alpha$ EstS9 $\Delta$ enzyme was determined at $60^{\circ} \mathrm{C}$ and $\mathrm{pH} 9.0$ using $3.6 \mathrm{mM}$ $p$-nitrophenyl acetate, $p$-nitrophenyl butyrate, $p$-nitrophenyl caprylate, and $p$-nitrophenyl decanoate in acetonitrile and $p$-nitrophenyl palmitate, and $p$-nitrophenyl stearate in $n$-hexane as substrates. The enzymatic reactions were stopped after $40 \mathrm{~min}$ with isopropanol, and the absorbance of reaction mixtures was measured at $405 \mathrm{~nm}$.

One unit of $\alpha$ EstS9 $\Delta$ esterase activity (U) was defined as the enzyme activity required for release of $1 \mu \mathrm{mol}$ of $p$-nitrophenol from $p$-nitrophenyl acetate per minute, at $60^{\circ} \mathrm{C}$ and $\mathrm{pH} 9.0$.

\section{RESULTS AND DISCUSSION}

In this study, we decided to produce in the Komagataella phaffii yeast and characterize two recombinant sequence variants of the EstS9 esterase from a psychrotolerant bacterium Pseudomonas sp. S9. The first one, called $\alpha$ EstS9N, consists of an N-terminal catalytic domain and a C-terminal AB-domain of native EstS9 esterase. The second protein, called $\alpha \mathrm{EstS} 9 \Delta$, is characterized by the lack of the C-terminal AB-domain of the EstS9 esterase, and its amino acid sequence was designed based on analysis of the InterProScan results. In both recombinant proteins the putative signal peptide of the EstS9 esterase was replaced by the signal peptide of Saccharomyces cerevisiae $\alpha$-mating factor $(\alpha-\mathrm{MF})$ enabling secretion of recombinant esterases into the culture medium. Also, a six-histidine tag (His-tag) was added to the C-terminus of both proteins to facilitate detection and purification (Fig. 1). Since the signal peptide should be removed by the Kex2 endopeptidase in the K. phaffii Golgi apparatus, the mature esterases secreted into the medium should have the same amino acid sequences as the EstS9N and EstS9 $\Delta$ proteins produced in E. coli (Wicka et al., 2016).

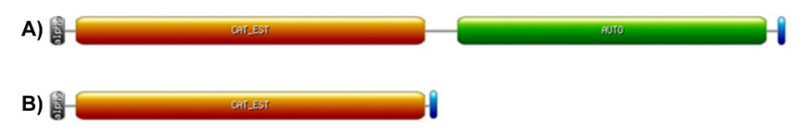

Figure 1. Topographic presentation of the Pfam domains for aEstS9N (A) and aEstS9 $\Delta$ (B)

Alpha, signal peptide of Saccharomyces cerevisiae a-mating factor (grey domain); CAT_EST, catalytic domain (orange domain); AUTO, autotransporter domain (green domain); His-Tag (blue domain). 
Construction of the recombinant K. phaffii X-33/ pPICZaestS9N and $K$. phaffii X-33/pPICZaestS9A strains

In order to produce two sequence variants of the EstS9 esterase from Pseudomonas sp. S9 in K. phaffii, two integrating plasmids named pPICZ $\alpha$ estS9N and pPICZ $\alpha$ estS9 $\Delta$ were constructed and used to transforme the yeast cells. Strong, methanol-inducible promoter of the alcohol oxidase 1 gene $\left(\mathrm{P}_{\mathrm{Aox} 1}\right)$ of the pPICZ $\alpha$ A plasmid was used for expression of the estS9N and estS9A genes in K. phaffii X-33 cells. This plasmid also contains sequences encoding the $\alpha-\mathrm{MF}$ signal peptide and the His-tag. The use of tightly regulated promoters, such as the $A O X 1$ promoter, holds advantages for overexpression of proteins. By uncoupling the growth from the production phase, biomass is accumulated prior to protein expression. Therefore, cells are not stressed by the accumulation of recombinant protein during growth phase, and even the production of proteins that are toxic is possible (Ahmad et al., 2014). Furthermore, this system has already been used successfully for the production of lipolytic enzymes in K. phaffii (Minning et al., 1998; Choi et al., 2004; Jiang et al., 2007; Yu et al., 2007; Wang et al., 2008; Ferrer et al., 2009; Yu et al., 2009; Eom et al., 2013; Huang et al., 2013; Sriyapai et al., 2015).

Because the heterologous gene expression level in $K$. phaffii is dependent on the copy number of the recombinant plasmid integrated into the genome, and a higher copy number confers higher resistance to Zeocin, the transformants were screened on YPD-agar plates containing $100-1000 \mu \mathrm{g} / \mathrm{mL}$ Zeocin. About $60 \%$ of all K. phaffii X-33/pPICZ $\alpha$ estS9N and K. phaffii X-33/ pPICZ $\alpha$ estS9 $\Delta$ transformants were highly resistant to Zeocin (they were able to grow on the culture medium with Zeocin at final concentration of $1000 \mu \mathrm{g} / \mathrm{mL}$ ). The PCR assays revealed that all yeast transformants highly resistant to Zeocin contained the aestS9N or aestS9 4 sequences as a result of integration of an appropriate recombinant plasmid into the $K$. phaffii X-33 genomic DNA.

\section{Expression of genes encoding the aEstS9 $\Delta$ and aEstS9N proteins}

Small-scale expression of the aestS9N and aestS9A genes in the K. phaffii X-33/pPICZ $\alpha$ estS9N and $K$. phaffii $\mathrm{X}-33 / \mathrm{pPICZ} \alpha \mathrm{estS} 9 \Delta$ cells was carried out in $50 \mathrm{~mL}$ of buffered methanol complex medium (BMMY) at $25^{\circ} \mathrm{C}$. Then, the post-culture fluids, cell lysates, as well as cellfree extracts (supernatants collected after centrifugation of cell lysates) were tested using the dot blot method. Dot blot results indicated presence of the $\alpha$ EstS9 $\Delta$ protein in the post-culture fluids, cell lysates and cell-free extracts of $K$. phaffii X-33/pPICZ $\alpha$ estS9 $\Delta$ strains no. 2, 3 and 4 (Fig. 2A). Analysis of dot blot results using BioRad's Quantity One Software showed that more than $50 \%$ of the single-domain esterase was secreted outside the $K$. phaffii cells. It was about $58 \%$ for recombinant strain no. $2, \sim 57 \%$ for strain no. 4 and $\sim 55 \%$ for strain no. 3 . In contrast, all of the $\alpha$ EstS9N protein was present in the cell lysate of $K$. phaffii X-33/pPICZaestS9N strain no. 6A (Fig. 2B), and it was not detected in the cell-free extract and post-culture fluid. Based on these results and analysis of the literature data (Rutherford \& Mourez, 2006; Wilhelm et al., 2011), it can be assumed that the $\alpha$ EstS9N protein is not transported outside the cell. Presence of the autotransporter domain can cause $\alpha$ EstS9N binding to cell membranes. Thus, in further research we decided to focus on production, purification and characterization of the $\alpha$ EstS $9 \Delta$ esterase.

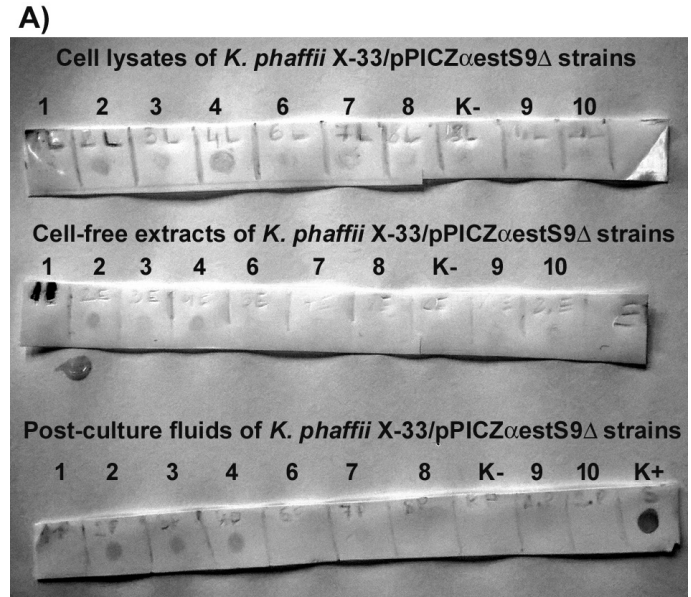

B)

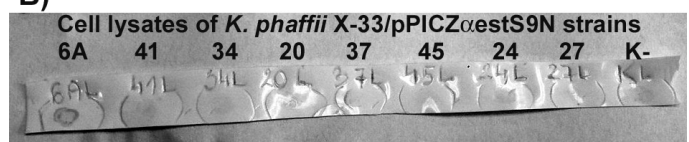

Figure 2. Dot blot assays of cell lysates, cell-free extracts and post-culture fluids of $K$. phaffii X-33/pPICZaestS9 $\Delta$ recombinant strains (A) and cell lysates of $K$. phaffii X-33/pPICZaestS9N transformants (B)

Dot blot tests were performed using HRP conjugated anti-His antibodies. $10 \mu \mathrm{L}$ samples were applied onto the membrane. Negative controls were samples of cell lysate, cell-free extract and post-culture fluid of $K$. phaffii $X-33$. Positive control was the protein with a His-tag.

\section{Production and purification of the aEstS9 $\Delta$ esterase}

The fed batch strategy was applied to production and secretion of the $\alpha$ EstS9 $\Delta$ esterase by recombinant K. phaffii X-33/pPICZ $\alpha$ estS9 $\Delta$ strain no. 2 . In the first stage, yeast biomass was multiplied in the medium containing glycerol as a sole carbon source, and then the cells were transferred to the medium containing methanol for induction of the aest59 $\Delta$ gene expression. The cultivation was carried out for 4 days, and methanol was added every $24 \mathrm{~h}$ to maintain the induction. The $\alpha$ EstS9 $\Delta$ esterase was then purified from the post-culture fluid by immobilized metal affinity chromatography (IMAC). SDS-PAGE analysis of the purified $\alpha$ EstS9 $\Delta$ protein showed two bands at $\sim 45$ and $\sim 35 \mathrm{kDa}$ (Fig. 3), which are close to the predicted molecular mass of the deduced $\alpha \mathrm{EstS} 9 \Delta$ protein with or without the $\alpha-\mathrm{MF}$ signal peptide, i.e. 42 and $33 \mathrm{kDa}$ respectively. This may indicate incomplete removal of the signal peptide from

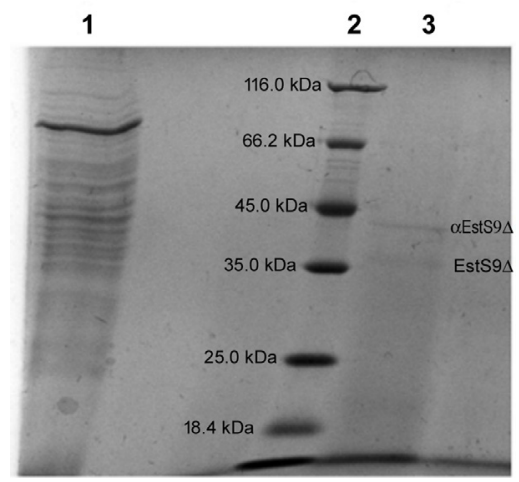

Figure 3. SDS-PAGE protein profiles:

(1) Post-culture fluid of K. phaffii X33/pPICZaestS9 4 , (2) Unstained Protein Molecular Weight Marker 116.0, 66.2, 45.0, 35.0, 25.0, 18.4, 14.4 kDa (Thermo Fisher Scientific, USA), (3) Purified aEstS9 $\Delta$ esterase 
Table 1. Relative activity of the aEstS9 $\Delta$ esterase against various chromogenic substrates

\begin{tabular}{lll}
\hline Substrate & $\begin{array}{l}\text { No. of carbon } \\
\text { atoms in the alkyl } \\
\text { chain }\end{array}$ & $\begin{array}{l}\text { Relative activity } \\
{[\%]}\end{array}$ \\
\hline$p$-nitrophenyl acetate & 2 & $100.0 \pm 2.1$ \\
\hline$p$-nitrophenyl butyrate & 4 & $79.0 \pm 3.3$ \\
\hline$p$-nitrophenyl caprylate & 8 & $37.7 \pm 0.5$ \\
\hline$p$-nitrophenyl caproate & 10 & $4.8 \pm 1.2$ \\
\hline$p$-nitrophenyl palmitate & 16 & $<0.01$ \\
\hline$p$-nitrophenyl stearate & 18 & $<0.01$ \\
\hline
\end{tabular}

recombinant protein. There are probably two forms of recombinant esterase in the resulting protein preparation. In summary, the production and purification resulted in $1.155 \mathrm{mg}$ of $\alpha$ EstS9 $\Delta$ esterase with a specific activity of $0.069 \mathrm{U} / \mathrm{mg}$ of protein per 1.8 liters of $K$. phaffii $\mathrm{X}-33 / \mathrm{pPICZ} \alpha \mathrm{estS} 9 \Delta$ yeast culture. For comparison, the EstS9 $\Delta$ esterase produced in the E. coli expression system as inclusion bodies, purified under denaturing conditions and renatured, had a specific activity of $0.0025 \mathrm{U} /$ $\mathrm{mg}$ of protein (Wicka et al., 2016).

\section{Substrate specificity, physicochemical characterization and determination of kinetic parameters of the aEstS9D esterase}

$p$-Nitrophenyl esters of different alkyl chain lengths were used to determine substrate specificity of the purified $\alpha$ EstS9 $\Delta$ esterase. As shown in Table 1 , the $\alpha$ EstS9 $\Delta$ enzyme is highly active towards short chain fatty acids (C2-C8), and has the maximum activity against the $p$-nitrophenyl acetate ester. Importantly, comparative analysis of results of different $p$-nitrophenyl esters hydrolysis by EstS9N (Wicka et al., 2016) and $\alpha$ EstS9 $\Delta$ enzymes revealed distinct differences in the substrate specificity for both compared proteins. In contrast to $\alpha$ EstS9 $\Delta$, the EstS9N enzyme showed the highest activity against $p$-nitrophenyl butyrate.

The effect of temperature on activity of the $\alpha \mathrm{EstS} 9 \Delta$ esterase was determined at temperatures ranging from 5 to $85^{\circ} \mathrm{C}$. As shown in Fig. 4, the maximum esterolytic activity was recorded at $60^{\circ} \mathrm{C}$. For comparison, the recombinant EstS9N esterase produced in the E. coli ex-

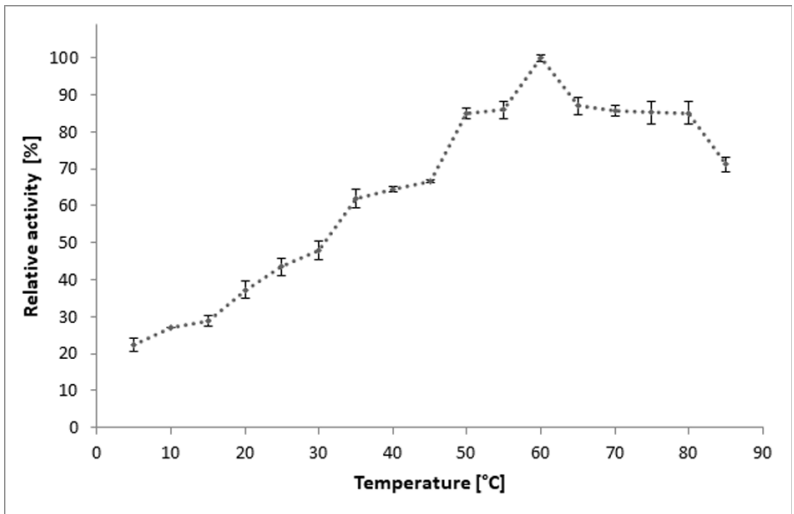

Figure 4. The effect of temperature on the recombinant aEstS9D esterase activity

The effect of temperature on the enzyme activity was assayed by incubating the aEstS9 $\Delta$ protein at a temperature ranging from 5 to $85^{\circ} \mathrm{C}$ with $3.6 \mathrm{mM} p$-nitrophenyl butyrate, in the Tris- $\mathrm{HCl}$ buffer $\mathrm{pH} 7.5$, for $40 \mathrm{~min}$. pression system was most active at $35^{\circ} \mathrm{C}$ and showed very little activity at $60^{\circ} \mathrm{C}$ (Wicka et al., 2016). The $\alpha$ EstS9 $\Delta$ esterase retained about $60 \%$ of its maximal activity at $35^{\circ} \mathrm{C}$.

Since $\alpha \mathrm{EstS} 9 \Delta$, a single-domain variant of the EstS9 esterase, is highly active in the temperature range of 50 to $80^{\circ} \mathrm{C}$, it can be compared to enzymes active at high temperatures, for example the EstEP16 enzyme which also exhibits the highest activity at $60^{\circ} \mathrm{C}$ ( $\mathrm{Zhu}$ et al., 2013) or the GDSL esterase from thermophilic bacterium Fervidobacterium nodosum Rt17-B1, which is active in the temperature range of $30-80^{\circ} \mathrm{C}$, with a maximum activity at $75^{\circ} \mathrm{C}$ ( $\mathrm{Yu}$ et al., 2010).

Moreover, $90 \%$ of the $\alpha$ EstS9 $\Delta$ esterase activity was retained after $3 \mathrm{~h}$ of incubation over a temperature range of 70 to $90^{\circ} \mathrm{C}$. Thus, the thermal stability of the $\alpha$ EstS9 $\Delta$ enzyme is significantly higher than that of the EstS9N protein, which was gradually inactivated by heat treatment at temperatures above $70^{\circ} \mathrm{C}$ (Wicka et al., 2016). The recombinant $\alpha$ EstS9 $\Delta$ esterase can be successfully compared to enzymes from thermophilic microorganisms, for example the GDSL esterase from Fervidobacterium nodosum Rt17-B1, which loses half of its activity after 80 minute incubation at $80^{\circ} \mathrm{C}(\mathrm{Yu}$ et al., 2010), or the thermostable esterase EstEP16 which retains $80 \%$ of its activity after $6 \mathrm{~h}$ of incubation at $90^{\circ} \mathrm{C}$ (Zhu et al., 2013). The increase in the thermostability of $\alpha \mathrm{EstS} 9 \Delta$ protein correlates with the shift in the optimal enzyme activity temperature.

The effect of $\mathrm{pH}$ on the esterolytic activity of the $\alpha$ EstS9 $\Delta$ protein was determined over a $\mathrm{pH}$ range of 2.0 to 12.0. As shown in Fig. 5, the enzyme is active over a $\mathrm{pH}$ range of 7.5 to 10.0 ( $>50 \%$ of maximum activity), and prefers alkaline conditions with maximum activity at $\mathrm{pH}$ 9.5. Furthermore, the results from the $\mathrm{pH}$ stability assays showed that approximately $100 \%$ of the enzyme activity was retained after $1 \mathrm{~h}$ of incubation at the pH range of 9.0-11.0 (Fig. 6). The previously described EstS9N esterase (Wicka et al., 2016) was also active and stable under alkaline conditions, especially at $\mathrm{pH} 9.0$. The EstEP16 enzyme (Zhu et al., 2013) and esterase from Fervidobacterium nodosum Rt17-B1 (Yu et al., 2010) show maximum activity at $\mathrm{pH} 8.0$ and 8.5 , respectively.

As shown in Fig. 7, the hydrolytic activity of $\alpha$ EstS9 $\Delta$ esterase against $p$-nitrophenyl butyrate as a substrate was clearly inhibited by $\mathrm{Ni}^{2+}$ and activated by $\mathrm{Mg}^{2+}$ ions. We also observed that the addition of ethylenedi-

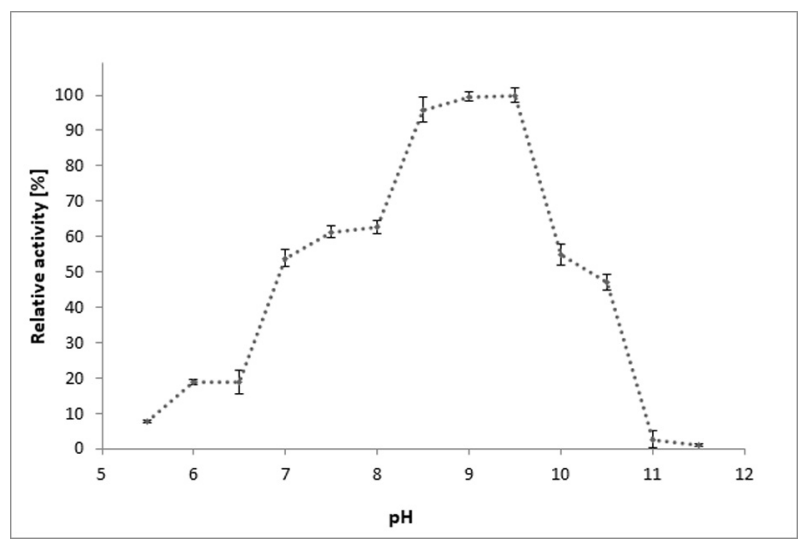

Figure 5. The effect of $\mathrm{pH}$ on the recombinant aEstS9 $\Delta$ esterase activity

The enzymatic activity was assayed at the $\mathrm{pH}$ values ranging from 2.0 to 12.0 , at $35^{\circ} \mathrm{C}$, with $p$-nitrophenyl butyrate as the substrate. 


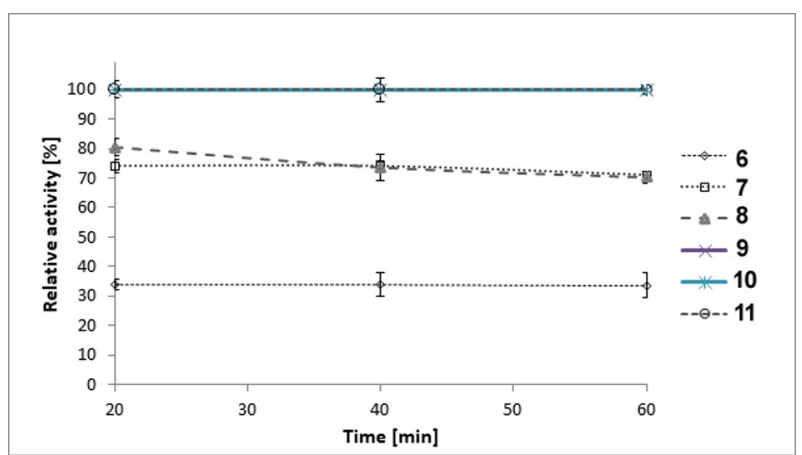

Figure 6. The effect of $\mathrm{pH}$ on the recombinant aEstS9 $\Delta$ esterase stability

The $\mathrm{pH}$-stability profile was determined by incubation of the enzyme for 20, 40 and $60 \mathrm{~min}$ at various $\mathrm{pH}$, and then the residual activity of the esterase was assayed at $35^{\circ} \mathrm{C}$ with $p$-nitrophenyl butyrate as the substrate.

aminetetraacetic acid sodium salt (EDTA) and oxidized glutathione to the enzyme markedly decreased its enzymatic activity (Fig. 8), whereas $\beta$-mercaptoethanol and dithiothreitol (DTT) were strong activators of the assayed enzyme. The EstS9N esterase was also inhibited by $\mathrm{Ni}^{2+}$ ions and oxidized glutathione, and activated by DTT (Wicka et al., 2016).

Studies of the kinetics of $p$-nitrophenyl butyrate and $p$ nitrophenyl acetate hydrolysis catalyzed by the $\alpha$ EstS9 $\Delta$ esterase revealed that the enzyme had lower affinity for $p$-nitrophenyl butyrate at $60^{\circ} \mathrm{C}$ (optimal temperature of action) than at $35^{\circ} \mathrm{C}$. It also exhibited low affinity for $p$-nitrophenyl acetate at $60^{\circ} \mathrm{C}$. Moreover, as shown in Table 2, the catalytic efficiency towards $p$-nitrophenyl butyrate $\left(k_{\text {cat }} / K_{\mathrm{m}}\right.$ value $)$ at $60^{\circ} \mathrm{C}$ was similar to the $k_{\text {cat }} / K_{\mathrm{m}}$ value for $p$-nitrophenyl acetate at $60^{\circ} \mathrm{C}$, and it was about two times lower than the one recorded at $35^{\circ} \mathrm{C}$. These results show that the single-domain esterase still has the properties of a cold-adapted enzyme, i.e. higher affinity for the substrate and higher catalytic efficiency at lower temperature. Unfortunately, values of kinetic parameters $\left(k_{\text {cat }}\right.$ and $\left.k_{\text {cat }} / K_{\mathrm{m}}\right)$ of $\alpha$ EstS9 $\Delta$, the single-domain esterase produced in $K$. phaffii, were much lower than those of EstS9N (a two-domain variant of the EstS9 esterase produced in E. coli). The catalytic efficiency of the $\alpha$ EstS9 $\Delta$ protein against $p$-nitophenyl butyrate at $35^{\circ} \mathrm{C}$ was only $0.2 \%$ of the value recorded for the EstS9N enzyme (Wicka et al., 2016). On this basis, it can be assumed that removal of the autotransporter domain of the EstS9 esterase had a negative effect on the enzyme activity.

\section{CONCLUSION}

The E. coli bacterium is the host of choice for expression of heterologous genes. However, some proteins do not fold properly in E. coli, leading to the formation

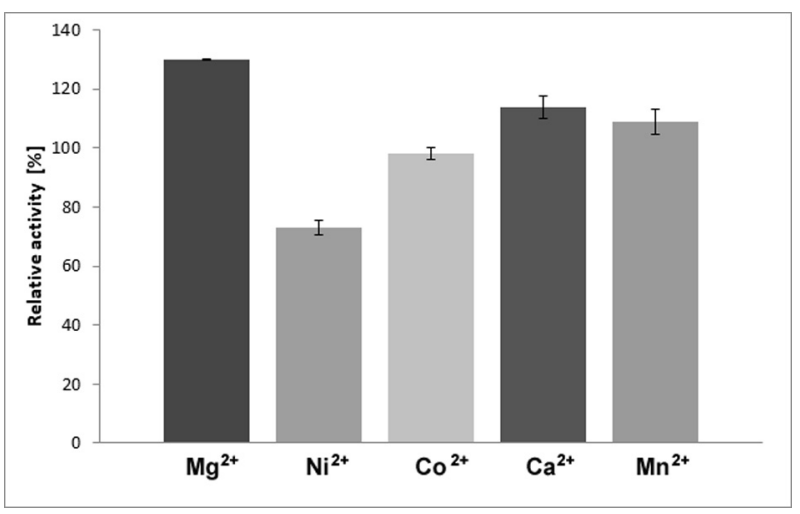

Figure 7. The effect of various metal ions on the recombinant aEstS9 $\triangle 4$ esterase activity

The enzyme was incubated for $60 \mathrm{~min}$ at $35^{\circ} \mathrm{C}$ with $5 \mathrm{mM}$ metal ions, and then the residual activity of the esterase was assayed with $3.6 \mathrm{mM} p$-nitrophenyl butyrate in the Tris- $\mathrm{HCl}$ buffer $\mathrm{pH} 9.0$, at $35^{\circ} \mathrm{C}$ for $40 \mathrm{~min}$.

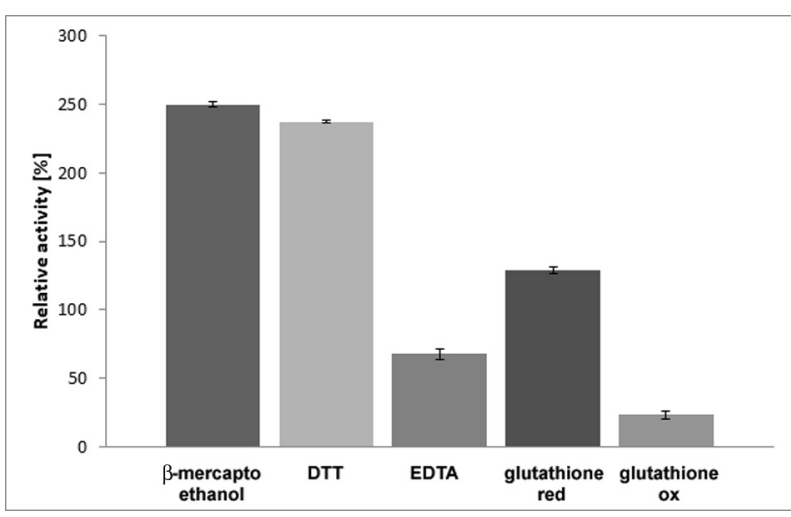

Figure 8. The effect of selected reagents on the recombinant aEstS9 $\Delta$ esterase activity

The enzyme was incubated for $60 \mathrm{~min}$ at $35^{\circ} \mathrm{C}$ with $5 \mathrm{mM}$ of $\beta$-mercaptoethanol, dithiothreitol (DTT), ethylenediaminetetraacetic acid sodium salt (EDTA), glutathione in the reduced and oxidized forms, and then the residual activity of the esterase was assayed with $3.6 \mathrm{mM} p$-nitrophenyl butyrate in the Tris- $\mathrm{HCl}$ buffer $\mathrm{pH} 9.0$, at $35^{\circ} \mathrm{C}$ for $40 \mathrm{~min}$.

of insoluble inclusion bodies. The choice of a different expression host, e.g. K. phaffii yeast, may allow production of the recombinant protein in a soluble form. Such a protein is more active and stable than its counterpart produced in E. coli cells in an insoluble form and refolded in vitro, as demonstrated for the single-domain variant of the GDSL-esterase of Pseudomonas sp. S9 (EstS9 $\Delta$ ). On the other hand, in the case of two-domain proteins, such as the EstS9 esterase, removal of the noncatalytic domain (autotransporter domain) may result in significant changes in the properties of the catalytic do-

Table 2. Kinetic parameters for $p$-nitrophenyl butyrate and $p$-nitrophenyl acetate hydrolysis catalyzed by the aEstS9 $\Delta$ esterase The enzyme was incubated with the appropriate substrate at a final concentration ranging from 0.72 to $5.4 \mathrm{mM}$, in Tris- $\mathrm{HCl}$ buffer $\mathrm{pH} 9.0$, at 35 or $60^{\circ} \mathrm{C}$, for different time periods. After appropriate incubation, the reactions were stopped by the addition of isopropanol, and the absorbance was measured at $405 \mathrm{~nm}$.

\begin{tabular}{|c|c|c|c|c|}
\hline Substrate & $\begin{array}{l}\text { Temperature } \\
{\left[{ }^{\circ} \mathrm{C}\right]}\end{array}$ & $\begin{array}{l}K_{\mathrm{m}} \\
{[\mathrm{mM}]}\end{array}$ & $\begin{array}{l}k_{\text {cat }} \\
{\left[\mathrm{s}^{-1}\right]}\end{array}$ & $\begin{array}{l}k_{\text {cat }} / K_{\mathrm{m}} \\
{\left[\mathrm{s}^{-1} \mathrm{mM}^{-1}\right]}\end{array}$ \\
\hline p-nitrophenyl butyrate & 35 & 0.727 & 0.034 & 0.047 \\
\hline p-nitrophenyl butyrate & 60 & 6.151 & 0.145 & 0.024 \\
\hline$p$-nitrophenyl acetate & 60 & 7.358 & 0.203 & 0.028 \\
\hline
\end{tabular}


main and have a negative effect on the enzyme activity. Therefore, in further research we plan to produce the EstS9 esterase in its natural host Psendomonas sp. S9 to determine the structure of the enzyme, its location in the cell and biochemical properties. First of all, we plan to determine if the two-domain protein is anchored in the outer membrane of Pseudomonas sp. S9, as in the case of the EstA esterase from Pseudomonas aeruginosa PAO1 (Wilhelm et al., 1999). At the same time, we plan to produce wild-type EstS9 esterase in E. coli cells using the pZErOS9 Lib1/NotI plasmid, containing a $3 \mathrm{~kb}$ genomic DNA fragment of Pseudomonas sp. S9 (Wicka et al., 2016), and characterize the recombinant enzyme. In addition, we plan to clone the full-length estS9 gene into the $\mathrm{pBAD} /$ Myc-His A expression vector, under the control of arabinose-inducible $\operatorname{araB} A D$ promoter, to produce the enzyme as a protein anchored in the outer membrane of E. coli and characterize the whole-cell biocatalyst. Such a biocatalyst is an attractive alternative for industry, as the enzyme bound to the cell surface (immobilized) is usually more stable than its free form and does not require multi-stage purification. Moreover, the whole-cell biocatalyst can be easily separated from the post-reaction mixture and used repeatedly, which reduces the cost of the process. On the other hand, the autotransporter domain of EstS9 esterase itself can be also used to transport and display other enzymes on the E. coli surface in order to obtain new biocatalysts with a biotechnological potential.

\section{REFERENCES}

Ahmad M, Hirz M, Pichler H, Schwab H (2014) Protein expression in Pichia pastoris: recent achievements and perspectives for heterologous protein production. Appl Microbiol Biotechnol 98: 5301-5317. https:// doi.org/10.1007/s00253-014-5732-5

Bollag DM, Edelstein SJ (1991) Protein methods. Wiley-Liss, New York

Choi YJ, Miguez CB, Lee BH (2004) Characterization and heterologous gene expression of a novel esterase from Lactobacillus casei CL96. Appl Environ Microbiol 70: 3213-3221. https://doi.org/10.1128/ AEM.70.6.3213-3221.2004

Eom GT, Lee SH, Song BK, Chung KW, Kim YW, Song JK (2013) High-level extracellular production and characterization of Candida antarctica lipase B in Pichia pastoris. J Biosci Bioeng 116: 165-170. https://doi.org/10.1016/j.jbiosc.2013.02.016

Ferrer P, Alarcón M, Ramón R, Benaiges MD, Valero F (2009) Recombinant Candida rugosa LIP2 expression in Pichia pastoris under the control of the $A O X 1$ promoter. Biochem Eng J 46: 271-277. https:// doi.org/10.1016/j.bej.2009.05.018

Hausmann S, Jaeger KE (2010) Lipolytic enzymes from bacteria. In Handbook of Hydrocarbon and Lipid Microbiology. Timmis KN ed, pp 1099-1126. Springer, Berlin, Heidelberg. https://doi. org/10.1007/978-3-540-77587-4_77
Huang J, Yang Z, Guan F, Zhang S, Cui D, Guan G, Li Y (2013) A novel mono- and diacylglycerol lipase highly expressed in Pichia pastoris and its application for food emulsifier preparation. Process Biochem 48: 1899-1904. https://doi.org/10.1016/j.procbio.2013.08.021

Jaeger KE, Eggert T (2002) Lipases for biotechnology. Curr Opin Biotechnol 13: 390-397

Jiang ZB, Song HT, Gupta N, Ma LX, Wu ZB (2007) Cell surface display of functionally active lipases from Yarrowia lipolytica in Pichia pastoris. Protein Expres Purif 56: 35-39. https://doi.org/10.1016/j. pep. 2007.07 .003

Minning S, Schmidt-Dannert C, Schmid RD (1998) Functional expression of Rhizopus oryzae lipase in Pichia pastoris: high-level production and some properties. J Biotechnol 66: 147-156

Rutherford N, Mourez M (2006) Surface display of proteins by Gramnegative bacterial autotransporters. Microb Cell Fact 5: 22. https:// doi.org/10.1186/1475-2859-5-22

Spohner SC, Müller H, Quitmann H, Czermak P (2015) Expression of enzymes for the usage in food and feed industry with Pichia pastoris. J Biotechnol 202: 118-134. https://doi.org/10.1016/j.jbiotec.2015.01.027

Sriyapai P, Kawai F, Siripoke S, Chansiri K, Sriyapai T (2015) Cloning, expression and characterization of a thermostable esterase HydS14 from Actinomadura sp. strain S14 in Pichia pastoris. Int J Mol Sci 16: 13579-13594. https://doi.org/10.3390/ijms160613579

Upton C, Buckley JT (1995) A new family of lipolytic enzymes? Trends Biochem Sci 20: 178-179

Wang CH, Guo RF, Yu HW, Jia YM (2008) Cloning and sequence analysis of a novel cold-adapted lipase gene from strain lip35 (Pseudomonas sp.). Agric Sci China 7: 1216-1221. https://doi.org/10.1016/ S1671-2927(08)60167-4

Wicka M, Wanarska M, Krajewska E, Pawlak-Szukalska A, Kur J, Cieśliński H (2016) Cloning, expression, and biochemical characterization of a cold-active GDSL-esterase of a Psendomonas sp. S9 isolated from Spitsbergen island soil. Acta Biochim Pol 63: 117-125. https://doi.org/10.18388/abp.2015_1074

Wierzbicka-Woś A, Bartasun P, Cieśliński H, Kur J (2013) Cloning and characterization of a novel cold-active glycoside hydrolase family 1 enzyme with beta-glucosidase, beta-fucosidase and beta-galactosidase activities. BMC Biotechnol 13: 22. https://doi.org/10.1186/14726750-13-22

Wilhelm S, Tommassen J, Jaeger KE (1999) A novel lipolytic enzyme located in the outer membrane of Pseudomonas aeruginosa. I Bacteriol 181: 6977-6986

Wilhelm S, Rosenau F, Kolmar H, Jaeger KE (2011) Autotransporters with GDSL passenger domains: molecular physiology and biotechnological applications. Chembiochem 12: 1476-1485. https://doi. org/10.1002/cbic.201100013

Yu M, Lange S, Richter S, Tan T, Schmid RD (2007) High-level expression of extracellular lipase Lip2 from Yarrowia lipolytica in Pichia pastoris and its purification and characterization. Protein Expres Purif 53: 255-263. https://doi.org/10.1016/j.pep.2006.10.018

Yu XW, Wang LL, Xu Y (2009) Rhizopus chinensis lipase: gene cloning, expression in Pichia pastoris and properties. I Mol Catal B Ensym 57: 304-311. https://doi.org/10.1016/j.molcatb.2008.10.002

Yu S, Yu S, Han W, Wang H, Zheng B, Feng Y (2010) A novel thermophilic lipase from Fervidobacterium nodosum Rt17B1 representing a new subfamily of bacterial lipases. J Mol Catal B Ensym 66: 81-89. https://doi.org/10.1016/j.molcatb.2010.03.007

Zhu Y, Li J, Cai H, Ni H, Xiao A, Hou L (2013) Characterization of a new and thermostable esterase from a metagenomic library. Microbiol Res 168: 589-597. https://doi.org/10.1016/j.micres.2013.04.004 